UDC 621.4.001

P. Hashchuk ${ }^{1}$, DSc, Prof., S. Nikipchuk ${ }^{2}$,

${ }^{1}$ Lviv State University of Life Safety, 35 Kleparivska Str., Lviv, Ukraine, 79007; e-male: petroh@meta.ua

${ }^{2}$ Lviv Polytechnic National University, 12 Bandera Str., Lviv, Ukraine, 79013; e-male: nikipch@gmail.com

\title{
GENERAL PRINCIPLES OF HARD-SOFT-TECHNOLOGIES APPLICATION TO MODELLING OF OPERATION PROCESS IN INTERNAL COMBUSTION ENGINES
}

\begin{abstract}
П.М. Гащук, С.В. Нікіпчук. Загальні засади застосування hard-soft-технології моделювання робочого процесу в двигуні внутрішнього згоряння. Досконалість поршневих двигунів в конструктивно-механічному сенсі без революційних змін в технології конструювання й виготовлення підвищити важко, а от досконалість в термодинамічному сенсі - «широке поле» для корисної активності інженерної науки. Аби якнайглибше проникнути в явище перетворення форм енергії - хімічної на теплову, а далі - теплової на механічну, необхідна багата на когнітивні можливості й належно адекватна модель «постійно змінних» у часі внутрішньомоторних процесів. Створити таку модель суто аналітичними й алгоритмічними засобами, як з'ясувалось, навряд чи можливо, а тому завжди паралельно до теоретичних досліджень доводиться застосовувати ще й експериментальні, що вимагають використання спеціального стендового обладнання. Поєднання натурності та віртуальності в моделюванні процесів, що перебігають у двигунах внутрішнього згоряння, дозволяє принципово підвищити якість інформаційного забезпечення процесу проектування і конструювання двигунів. Такий підхід можна назвати hard-soft-технологією пізнання. Мета роботи - уточнити засади раціонального поєднання натурального і віртуального модельних середовищ у єдину систему, втілюючи тим самим hardsoft-технологію моделювання робочого процесу в двигуні внутрішнього згоряння. Загалом «інтегрувати», якщо можна так казати, систему описових рівнянь хоч у якій формі бездоганно може лише реальність. Відтак гармонійне поєднання натурного модельного і віртуального модельного в рамках будь-якої парадигми дозволяє поглибити пізнання закономірностей продукування механічної енергії в тепловому двигуні. Виходячи з загального, в значній мірі теоретичного, опису теплопередачі і спираючись на рівняння теплопередачі Ньютона та теорії подібності, тим не менш, коли заходить мова про адекватне оцінювання тепловіддачі через стінки робочого простору двигуна, доводиться вдаватись до коректувальних дій, здійсненних тільки за допомогою безпосередніх вимірювань. Саме безпосередні вимірювання в натурному середовищі температурних параметрів робочого простору двигуна створюють інформаційну основу для теоретичних узагальнень у віртуальному середовищі.

Ключові слова: двигун внутрішнього згоряння, модельний робочий простір, теплотворення, теплоспоживання, моделювання,
\end{abstract} hard-soft-технологія

P. Hashchuk, S. Nikipchuk. General principles of hard-soft-technologies application to modelling of operation process in internal combustion engines. The perfection of the piston engines in the constructive-mechanical sense without revolutionary changes in the technology of design and manufacturing is difficult to raise, but the perfection in the thermodynamic sense is a "broad field" for the useful activity of engineering science. In order to penetrate as much as possible into the phenomenon of transformation of forms of energy chemical to thermal, and then - thermal to mechanical, it is necessary to have a rich cognitive ability and a properly adequate model of "constantly variables" in the time of the intraomotor processes. To create such a model purely analytical and algorithmic means, as it turned out, is hardly possible, and therefore always in parallel with the theoretical studies have to be applied also experimental, requiring the use of special bench equipment. The combination on natural and virtual approaches to the modelling of processes that occur in the internal combustion engines enables to increase considerably the information support of engines design processes. This approach can be named the hard-soft-technology of comprehension. The aim is to specify the principles of rational combination of natural and virtual modelling environments into a united system employing, in this way, the hard-soft-technology of operating process modelling in the internal combustion engines. Generally, it is only the reality that is able to implacably "integrate", so to say, the system of descriptive equations in any possible form. Consequently, the harmonious combination of natural modelling and virtual modelling within the framework of any paradigm enables to enhance the comprehension of mechanic energy production principles in the thermal engines. Proceeding from a general and to a considerable extent theoretical description of heat transmission and taking into consideration the Newton heat-transfer equation and the theory of similarity, however, when an adequate evaluation of heat emission through the walls of the engine's operation space is discussed, the corrective measures performed solely by means of direct measurements are required. It is the direct measurements in the natural environment of engine's operating space thermal parameters that create the informative grounds for theoretical generalizations in the virtual environment.

Keywords: internal combustion engine, model working space, heat generation, heat consumption, modelling, hard-soft technology

Introduction. In view of the enormous variety of applications of the internal combustion piston engine (ICE), the question of an objective comparative assessment of the real (embodied) and potential (achievable in principle) levels of its perfection is all the more acute. Modern studies of the efficiency DOI: 10.15276/opu.2.55.2018.04

(c) 2018 The Authors. This is an open access article under the CC BY license (http://creativecommons.org/licenses/by/4.0/). 
of such engines make it clear that all possibilities of optimizing their properties have not been disclosed yet. The efficiency of the engine is appropriate to consider in two fundamentally different aspects - thermodynamic and structural-mechanical. The perfection of the piston engines in the constructive-mechanical sense without revolutionary changes in the technology of design and manufacturing is difficult to raise, but the perfection in the thermodynamic sense is a "broad field" for the useful activity of engineering science. In order to penetrate as much as possible into the phenomenon of transformation of forms of energy - from the chemical (chemical) to the thermal, and then - the thermal to the mechanical, it is necessary to have a rich cognitive capabilities and a properly adequate model of "constantly variables" in the time of internal motor processes.

Analysis of recent research and publications. It is hardly possible to create this model by purely analytical and algorithmic means, therefore it is always necessary to use experimental experiments that require the use of special bench equipment [2] in parallel with theoretical studies. In this case, it is advisable to combine the analytical-algorithmic model of the structure of the actual working space of a real engine in general. The combination of the level and the virtuality in the simulation of the processes occurring in internal combustion engines, allows to substantially improve the quality of information provision of the design and engine design process. Such an approach can be called hard-softcognitive technology.

The purpose of the work is to clarify the principles of a rational combination of natural and virtual model environments into a single system, thus embodying hard-soft technology for simulating the workflow in the internal combustion engine so that we will not have to find out if, at times, our assumptions are influenced by our observations.

Research. The model, as you can suppose, is a qualitatively specific form and a means of scientific knowledge, as well as reflection / accumulation / dissemination of knowledge. The model can be governed by any kind of mentally constructed or actually existing system, which is in quite certain relations with a certain other system, which the subject treats as an object, an original, a nature. It must satisfy the following conditions:

- reflectivity / analogy, when there is a relationship between the model and the original, the form of which is clearly outlined and unambiguously fixed;

- representativeness, when in the process of scientific knowledge and distribution of knowledge the model substitutes the object, the original, the nature;

- extrapolation, when studying the model allows receiving new information (unknown information) about the original;

- terminological delineation, when it is in the model environment that ripens, establishes, acquires a clear and accurate recognition of the object in relation to the object.

The technological combination of naturalness and virtuality in the simulation of processes occurring in internal combustion engines reflects the generalized principal scheme shown in Fig. 1.

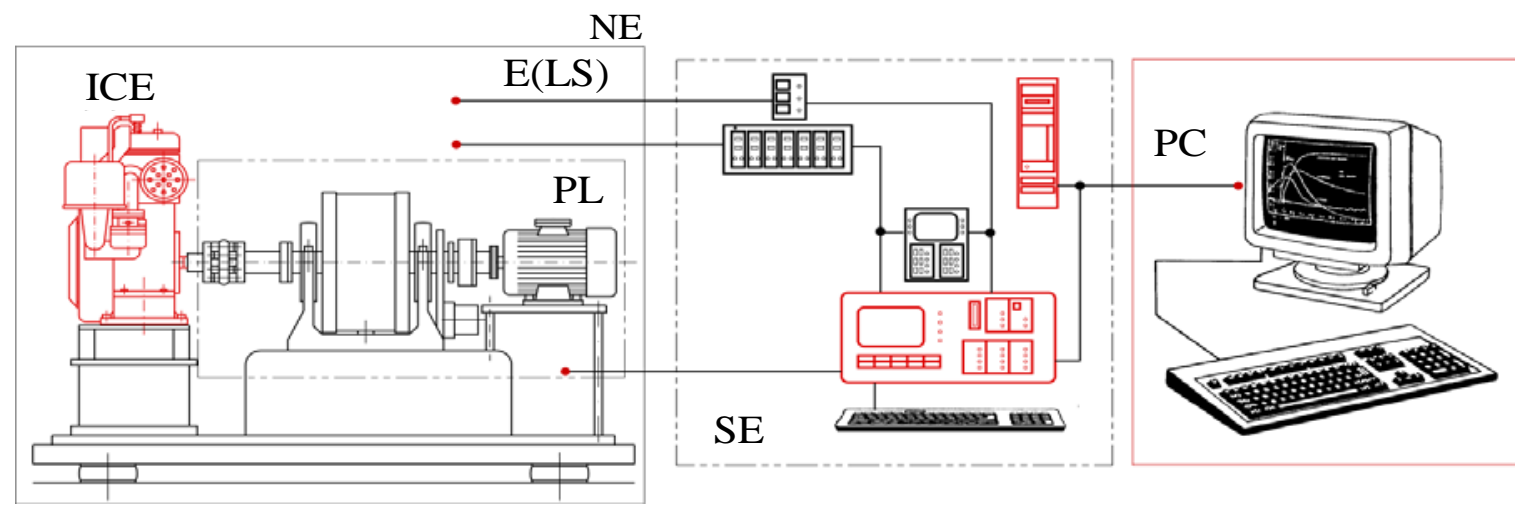

Fig. 1. Scheme of the program-oriented model environment

The model workspace is immersed in its own internal combustion engine (ICE), if under it means the totality of all systems that provide the normal activity of the working space. The engine, together 
with the model working space, is immersed in the environment $\mathrm{E}$ (in its living space LS), which includes, in particular a loader PL (with electric, for example, brake and engine) and the entire sensor system. Listed together - this is the so-called natural environment (NE), which is obliged to "communicate" with the software environment of the SE. Everything that can not or can not tell the environment, is obliged to report the software environment through a personal computer PC, and vice versa.

Of course, the living space LS of the engine must be controlled (must be conditioned) so that you can simulate various external operating conditions for operating its working space (ICE), The software environment $\mathrm{SE}$ is subject to one or another program, one or the other algorithmic, which absorbed the most reliable achievements of theory and empiricism. Actually the software environment and determines the structure and functions of the environment.

Very well-known is, for example, the software-algorithmic environment CFD Code AVL FIRE. There seems to be a complete solution to the problem of adequacy and validation. Everyone who works in it as if trusting each other, as if respecting and recognizing the results of research each other ... And in the software environment CFD Code AVL FIRE there are pre-set tight frames of knowledge, which can be expanded only by adding real working space.

For the simulation of thermal phenomena that run in engine cylinders, a system of three equations is used in various forms: the equation of the law of conservation (indispensability) of energy, the equation of the law of conservation (non-destruction) of matter (matter) and the equation of the thermodynamic state of the working body. In this case, it is necessary to operate with four variables: the pressure of gases in the cylinder or its part, the corresponding temperature of the working body or its part, the energy contained in the working body or part thereof, and the mass of the working body or part thereof. Consequently, the original system of equations should be identified either by an additional equation, or by informational, by specifying the function of the change in the time of one of the listed values. This function is, in particular, a mutual change in pressure and volume between the display chart. But this does not guarantee unambiguousness.

The theory of thermal phenomena in internal combustion engines has a long history and is based on the classical representations of the thermodynamics of ideal gas [3 - 5]. The criterion for the ideal of any thermodynamic body can be the value $\zeta=p v /(\mathrm{R} T)$ that for a perfect gas acquires a purely single value $\zeta \equiv 1$ ( $p$ - pressure, $v$ - specific volume, $\mathrm{R}$ - gas constant, $T$ - absolute temperature). The second measure of the degree of ideality is the specific enthalpy, which for the ideal gas is defined as the sum of "heat meters" of its individual components:

$$
h=\sum_{i=1}^{n} g_{i} \int_{0}^{t} c_{p i} d t
$$

where $c_{p i}$-the specific heat of the $i$-th component of the gas, the proportion of which in the mixture is $g_{i}$;

$t$ - temperature;

$n$ - total number of components.

As far as the real thermodynamic body of the internal combustion engine differs by meter $\zeta, h$ from the ideal gas can be traced by the ones given in Fig. 2 diagrams (only one concrete example of a workflow in a diesel turbocharged engine with an excess air $\lambda=1.7$ and an average effective pressure $\left.p_{e}=1.3 \mathrm{MPa}[6]\right)$.

The process of changing the state of the real thermodynamic body from the moment A completes the process of admission to the moment $\mathrm{B}$ of the start of the process of emission corresponds to a thickened line; other lines reflect the level of deviation from ideal in relative (percentage) units $\delta_{\zeta}=(\zeta-1) \cdot 100 \%$ (Fig. 2a), $\delta_{h}=\left(h_{R}-h_{I}\right) / h_{I} \cdot 100 \%$ (Fig. $\left.2 b\right)\left(h_{R}, h_{I}\right.$, the enthalpies of real and ideal gases; $h=0$ for $p=0.101 \mathrm{MPa}$ and $t=0{ }^{\circ} \mathrm{C}$ ).

From the diagram on Fig. $2 a$ it follows that the $\zeta$-meter measures the degree of deviation of the real working body from the ideal in the working cycle to not more than $4 \%$ (the largest deviation corresponds to the point $C$ ). According to the enthalpy index, the greatest deviation is possible due to the 
combination of high pressure and temperature (Fig. 2b, point) and such low temperatures, when some components of the real thermodynamic body reach saturation or condensation. However, for the process under consideration, the deviation for the $h$-meter does not exceed $\pm 1 \%$.
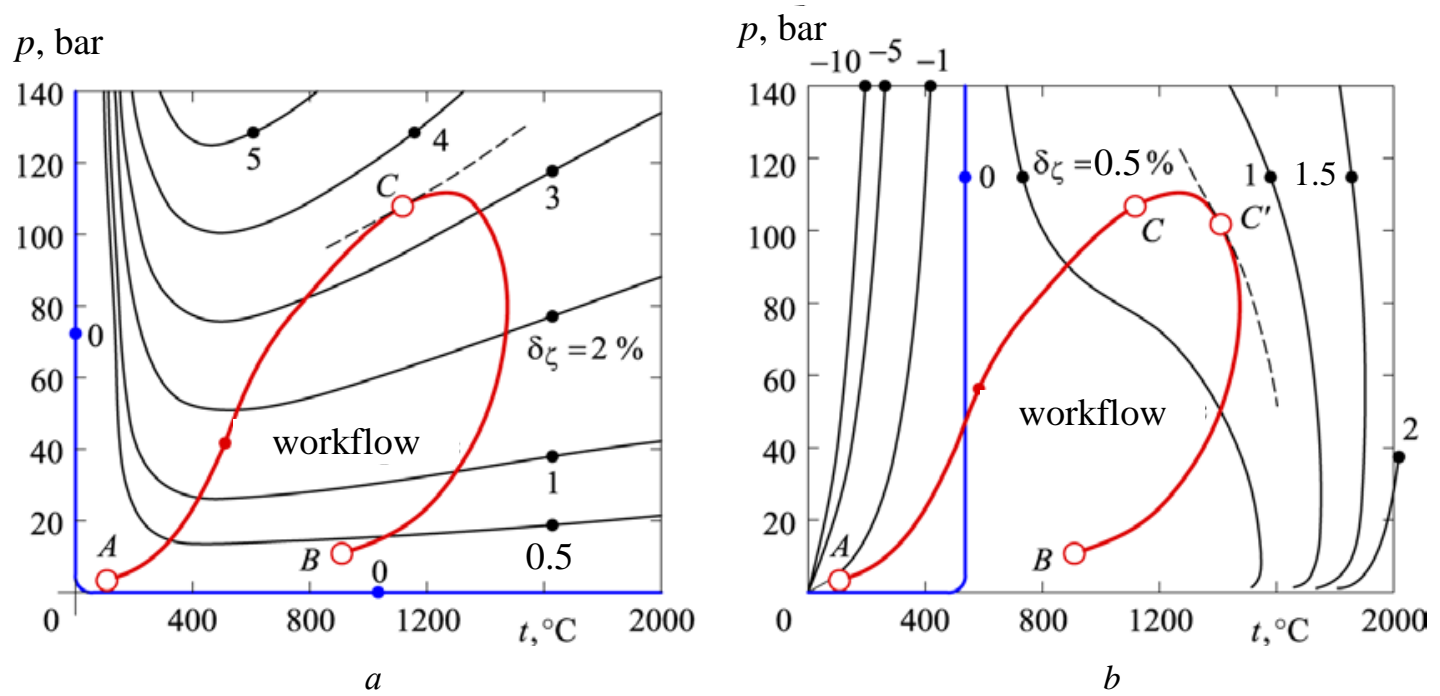

Fig. 2. The formalized diagrams represent the degree of difference between the real thermodynamic body and the ideal gas for two criteria

This level of deviation in many cases can be considered quite acceptable [6]. But we must also consider that in the case of modeling of thermodynamic phenomena in engines it is necessary to resort to other idealized assumptions. The most primitive assumption, which is rarely mentioned "aloud", is the assumption of gas cylinder impermeability in the case of closed valves. The error associated with it is steadily small in the case of modeling the work of a warmed engine (engine in condition) under the load. But in the case of starting the engine (especially diesel) at low ambient temperatures, the leakage of the working body outside the cylinder can reach $20 . . .30 \%$. And the working processes in engines must be interpreted as polytropic. Ideally, it would be possible to consider such a working cycle of the engine, the indicator diagram $p=p(V)$ ( $p$ - pressure, $V$ - volume) which in the logarithmic coordinate system would constitute the only segments of the straight lines. In the first approximation (mostly for qualitative signs), the assumption of polythroplasty is quite probable. But in quantitative terms, the deviation of real cycles from polytropic forces is forced to resort to fundamentally different approaches to modeling. First of all, it concerns the model reproduction of heat generation, heat transfer, heat transfer [2, 7]. But in fact these processes can not be satisfactorily adequate to purely analytical descriptive. It remains to admit that at present, adequate modeling of work processes in an internal combustion engine can not be limited to analytical and algorithmic means (and especially - purely empirical).

There is not one way to reflect the combustion process in an analytical form. So, some researchers have focused on determining the combustion rate of the mixture by using the chemical equations of fuel and air reaction. Others attempted to simulate the law of fuel injection in the engine and calculate the rate of conversion of energy based on the size and patterns of the propagation of droplets of fuel. Sometimes, based on the principles of the biomolecular combustion theory, analytical dependencies were established that linked the combustion rate with the law of sending fuel, the share of burned fuel, and the like. The disadvantage of all these models is that they require a lot of simplifications that result in noticeable deviations of the model process from the real one, or require unimaginable efforts for their service.

The most attractive, given the ease of use and visibility of the interpretation of the results obtained, are the so-called single-band, dual-zone simplified, and actually two-zone models of thermodynamic transformations in the working space of the thermal engine. Through the prism of a one-zone 
model, the working space of the engine is seen as a single entity, at all points of which at any moment the temperature, the composition of the working gases are the same. Within the simplified dual-zone model, there is an area of combustion space where the working mixture is already burned, and the zone where the mixture is still untouched, but for different values of the excess air ratio, the temperature in the two zones is one and the same. But, in the framework of the actual dual-zone model, the temperature in the zones is different and heat exchange is taking place between these zones.

Finding ways to control combustion in cylinders of internal combustion engine has long been considered one of the main sources of progress in its improvement [8]. Since the invention of the internal combustion engine, their development has faced the problems of instability of the combustion process, the main of which was the problem of detonation. The "mechanical" concept of the fight against detonation, for example, was proposed by Ricardo (1941), was to use special configurations of cylinder heads and piston bottoms, which are used in various versions to this day. In general, the problem of improving combustion in the internal combustion engine can be reduced to the problem of optimal distribution in space and time of potential carriers of thermal energy, cells of multi-point ignition and everything else that accompanies the process of heat generation and heat transfer.

The efficiency of combustion can be estimated by guiding various features. A very natural sign is the light of a combustion space or a certain part of it. For example, even internal pressure sensors are used for the internal cylinder in the electronic control systems of the internal combustion engine with feedback for the analysis of the combustion process. They are adapted so that it is possible to evaluate the characteristics of the heat and determine the average indicator pressure $p_{i}$. Along with the measurement of pressure, information on combustion can be obtained by registering the luminosity of the reaction zone and combustion products. It is worth mentioning the studies of the period 1930...1960s, in which the radiation of a number of molecules and radicals in the combustion process in internal combustion engines was analyzed for the purpose of measuring the temperature of gas in a cylinder, determining the mechanism of reactions in a cold flame and studying the kinetics of formation of nitrogen oxides. Subsequently, with the aid of fiber optics, investigations of the initial stages of combustion, the process of propagation of flame and detonation in internal combustion engines with spark ignition, as well as the possibility of controlling the quality of the mixture formation and the completeness of combustion were studied.

In [9], for example, an attempt was made to extend the range of measurable characteristics of the combustion process by means of an optical sensor and analysis of the relationship between pressure in the cylinder and recorded light. Although detailed combustion information is contained in the spectra of $\mathrm{CH}, \mathrm{C}$, and $\mathrm{OH}$ particles, special importance was given to the thermal radiation of $\mathrm{H}_{2} \mathrm{O}$ particles in the near-infrared region between 900 and $1000 \mathrm{~nm}$, where the spectral sensitivity peak of an inexpensive silicon photodetector is located. The thermal radiation of the walls of the combustion chamber in this band does not create strong interference. Of the several emission lines of $\mathrm{H}_{2} \mathrm{O}$ that exist in the flame in the range $900 \ldots 1000 \mathrm{~nm}$, one of the most intense ones was chosen $-927.7 \mathrm{~nm}$.

The research was carried out on a special one-cylinder engine with forced inflammation (compression ratio $-\varepsilon=8.9$; piston stroke / cylinder diameter $S / D=92.0 / 87.7 \mathrm{~mm} / \mathrm{mm}$, working volume $V_{h}=0.56 \mathrm{dm}^{3}$ ). The experiments included the measurement of the engine speed, torque, fuel and air consumption, temperatures and pressures on the inlet and outlet and in the systems of cooling and supply of fuel, as well as the determination of concentrations of carbon monoxide, carbon dioxide, oxygen, nitrogen oxides, hydrocarbons in exhaust gases to control the composition of the mixture. Reflection was carried out at intervals of 1 degree turn of a crankshaft series by 100 working cycles. The radiation from the combustion chamber through the light-receiving device and a quartz fiber optic cable of $3 \mathrm{~mm}$ in diameter and $610 \mathrm{~mm}$ in length were transmitted to the monochromator focusing lens, allocating strips of $927.7^{ \pm 20} \mathrm{~nm}$. The detector, based on a silicon photodiode with a peak of about $900 \mathrm{~nm}$, worked in a generator mode to minimize the noise current while maintaining an adequate frequency response. The data processing system allowed the absolute values of pressure in the cylinder to be determined. The zero level of the luminance signal was reduced to the lower dead point of the suction cycle. 
It turned out that despite the fact that the nature of the relationship between maximum integral luminosity $l_{\max }$ and maximum pressure $p_{\max }$ in the engine cylinder through the manifestation of many factors is extremely complicated. However, that this correlation correlation is close to the linear for all variations of regime parameters. The $l_{\max }$ is even more susceptible to combustion conditions than $p_{\max }$, in particular in the case of strong cyclic instability caused by detonation and infiltration passes. A multiple regression analysis with a quadratic response function has shown that there are satisfactorily predicted dependencies

$$
p_{\max }=F\left(n_{\mathrm{e}}, p_{\mathrm{int}}, l_{\max } / l_{\max , \text { base }}, \varphi_{l}\right), \varphi_{p}=F\left(n_{\mathrm{e}}, p_{\mathrm{int}}, l_{\max } / l_{\max , \text { base }}, \varphi_{\mathrm{l}}\right),
$$

where $n_{\mathrm{e}}$ - engine shaft speed;

$\varphi_{l}$ and $\varphi_{p}<\varphi_{l}$ - the rotation angle of the shaft, corresponding to the values $l_{\max }$ and $p_{\max }$;

$p_{\text {int }}-$ pressure on the inlet;

$l_{\max , \text { base }}$ - maximum luminosity in a cylinder in the mode of operation of the engine taken for the base comparative.

Similar correlations between values were also estimated $l_{\max }$ and $d Q_{\max } / d \varphi$ (maximum rate of heat dissipation), $\varphi_{l}$ and $\varphi_{d Q / d \phi}$ (the angle of the crankshaft, corresponding to the maximum value $d Q_{\max } / d \varphi$ the rate of heat dissipation), $l_{\max }$ and $p_{i}$.

Such a correlation can be useful in the feedback control systems individually in each cylinder, in particular in the case of unstretched control, as well as in the case of detecting incomplete combustion, ignition passes and the transition to detonation. Optimizing combustion, you can focus on the maximum efficiency, the minimum $\mathrm{NO}_{x}$ emissions, the minimum intercity distribution of parameters or the like. At brilliance you can adjust the angle of ignition or to choose the composition of the mixture. For example, the study [9] demonstrated the possibility of using the luminance signal to predict the average indicator pressure based on the current data averaging over 4 cycles (instead of 100) with exponential weight, that is, with partial smoothing of cyclic variations for a small time delay.

Of course, one should still understand the physico-chemical laws that underlie these correlations. It is necessary to investigate the sensitivity of the results obtained to the kind of fuel, to the location of the lens sensor, to the environmental parameters. For prolonged use of the sensors there will be a problem of their contamination and reliability. If the luminance sensor is introduced into the control system, it will also be necessary to evaluate the quality of electrical signals, the rationality of choosing the number of cycles that guarantee representative averaging.

It is clear that the high level of the described correlation line can be observed even when the base meter takes the value $p_{\max }$ (and not $l_{\max }$ ). It is the pressure (pressure sensors) that best fit into the model working space of the internal combustion engine. Therefore, it would be advantageous to simulate the heat processes to reduce to the measured pressure of gases in the working space of the engine to reproduce the heat generation, and vice versa, taking as a basis the prescribed flow of heat generation, calculate the pressure of gases in the cylinder. The advantage of this modeling is the relatively high accuracy of the results of calculations, as well as the possibility of studying the influence of various factors and parameters on the process of heating, without involving excessively complex experimental measurements for this. But it will not be possible to get around without experimental information.

In order to determine, in particular, the average indicator pressure $p_{i}$ in the engine operating cycle, it is necessary to establish the relationship between the identified process of changing the current pressure $p$ in the cylinder and the change in cylinder working volume or, correspondingly, the angular position of the crankshaft, measured normally by the sensor mounted on the crankcase. Very visual are so-called indicator charts, Fig. 3, 4 ( $S$ - piston stroke; $\varphi$ - angle of rotation of the crankshaft; $C$ point reflecting the moment of ignition of the fuel mixture, which, we think, it is easier to notice in coordinates $\varphi-p ; V$ - the volume of the working space of the cylinder; $V_{c}$ - the volume of storage of 
the combustion; UDP and LDP - upper and lower dead points). At the same time, two types of errors are possible. One of them is associated with inaccuracies in determining the angular position of the crankshaft, and the other - with inaccuracy in determining the actual pressure in the cylinder.
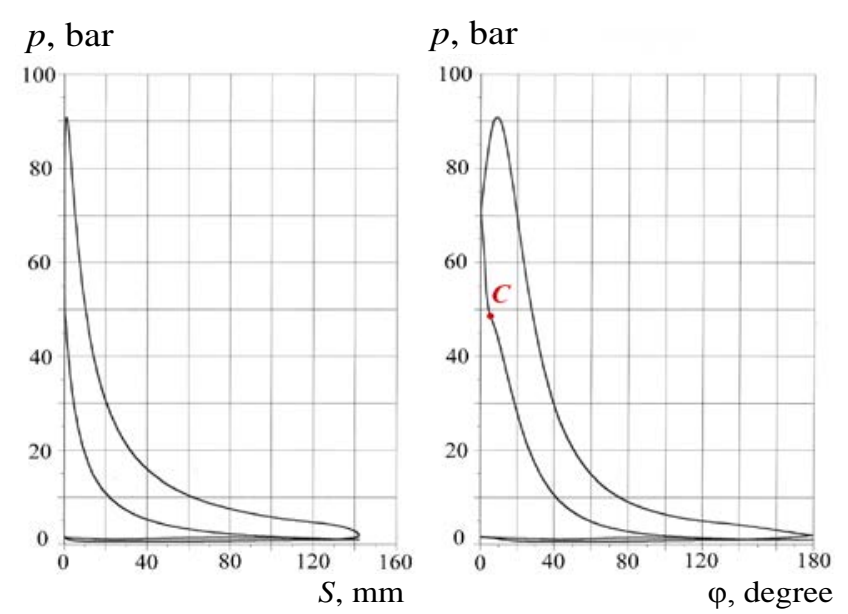

Fig. 3. Examples of the indicator diagram

$$
\left(n_{e}=1500 \mathrm{~min}^{-1}, p_{e}=6.5 \mathrm{bar}\right)
$$

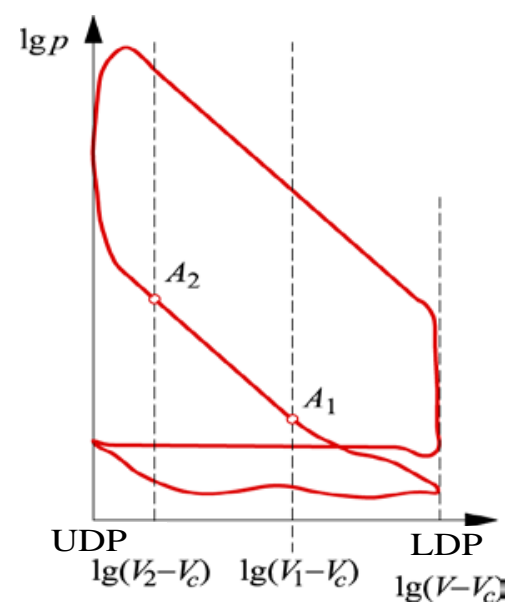

Fig. 4. Typical connection between volume of working space and pressure in it in logarithmic coordinates

In addition to possible errors in the step of marking scales, the possible causes of errors in determining the angular position of the crankshaft may be possible phase delays in the elements of the electronic signal processing system, tolerances on the size of the angles between the knees, and the crankshaft's steep oscillations. Errors in determining the dead points (positions) of the impact mechanism are the cause of inaccurate alignment of the sensor of the angle of rotation of the crankshaft. The effect of this error on the accuracy of the results of the display of experimental information is well studied. The second group of errors is a consequence of, so to speak, inaccuracies in the identification of the actual pressure. The pressure is measured by quartz sensors with a serially included charge amplifier, the output of which removes an analog signal in the form of voltage in the circle of electric current, proportional to the ideal pressure in the cylinder. Comparative studies of several quartz sensors of different structures on the same cylinder of the internal combustion engine when displaying the same working cycle indicate that the indicator diagrams necessarily have deviations from the averaged reflection data, since practically all pressure sensors distort their own "in their own way" information. A reliable estimation of the quality of the sensor is possible only when tested on a special stand with simulated conditions in the cylinder of the internal combustion engine.

Efficiency of use of pressure sensors (on an example of a diesel engine) and possible errors of their displays are thoroughly studied, for example, in $[10,11]$. Combustion in the internal combustion engine occurs at high pressures and temperatures, which causes the heat transfer in the wall of the pressure sensor to increase by an order of magnitude compared with the gas exchange phases.

In the process of release, though to a lesser extent, the heat is brought to the walls of the sensor, while in the process of intake, on the contrary, the heat is given to the working body. Such fluctuations of the heat flow are superimposed on the actual temperature field of the sensor and becomes the most significant source of errors in measuring the pressure in the cylinder, even at the steady state of the internal combustion engine.

By changing conditionally the location of dead points (dead positions of the swarm mechanism), it is possible to distort the indicator working cycle, Fig. 5 , to the actual unknowingness ( $p$ - cylinder pressure; $S$ - piston stroke; $\varphi$ - angle of rotation of the crankshaft; $\Delta \varphi$ - deviation of the dead point from its true location). The information about the change $w_{i=} w_{i}(\varphi)$ of the specific indicator work $w_{i}$ with the rotation $\varphi$ of the engine shaft, Fig. 6. 

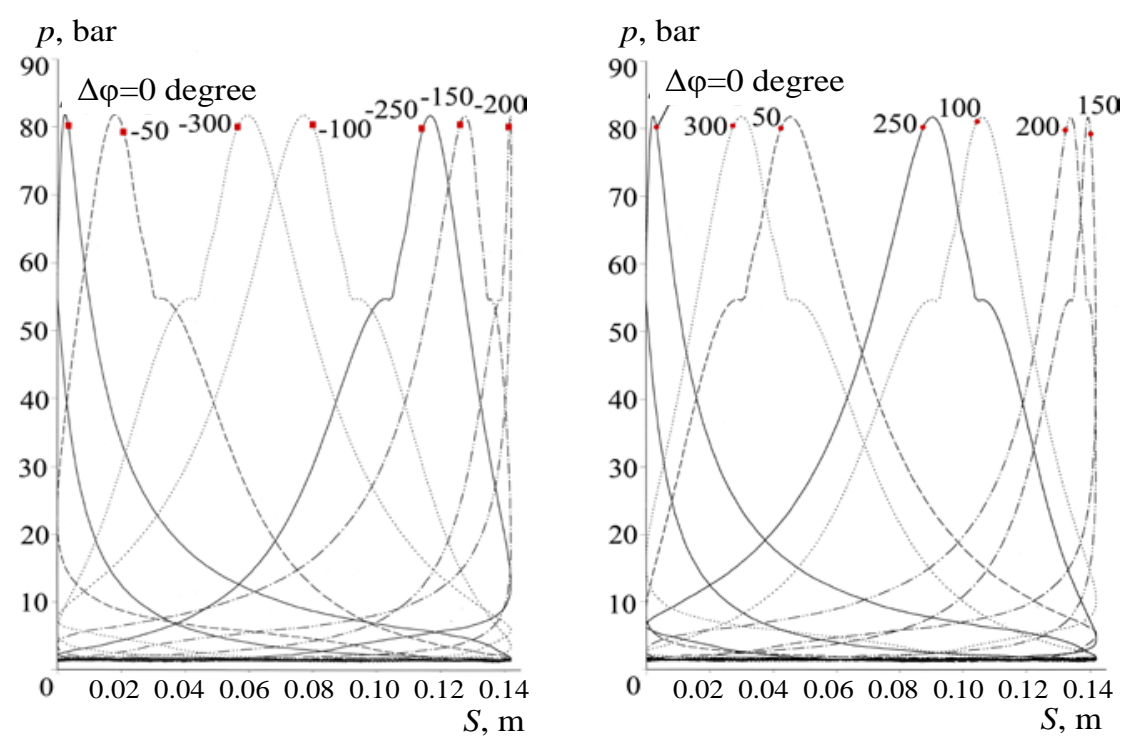

Fig. 5. Artificial distortion of indicator charts by changing the location of dead points

Inaccuracy in the determination of the position of dead points significantly affects the identification of the process of changing the intensity of heat generation due to combustion of fuel, Fig. 7 ( $Q_{\text {shd }}-$ specific heat dissipation).

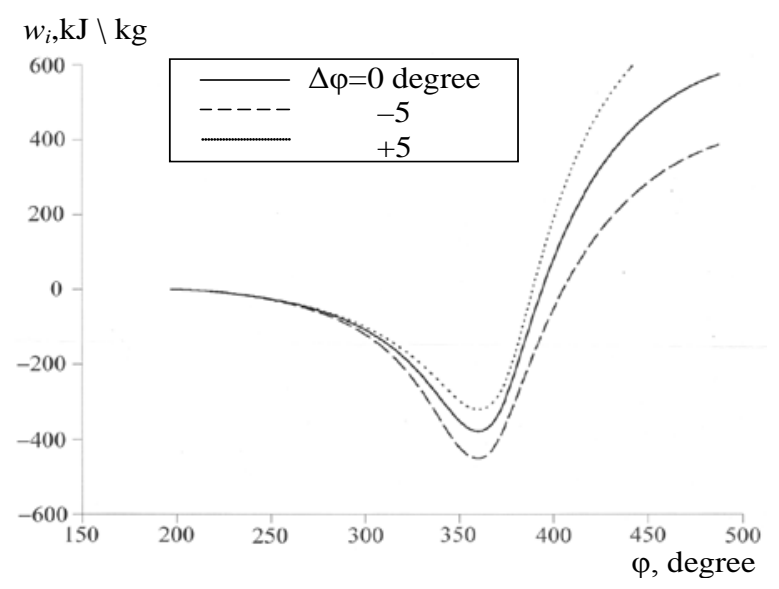

Fig. 6. Distortion of the schedule of change of indicator work in the case of inaccurate definition of the upper dead point in the hard-soft environment

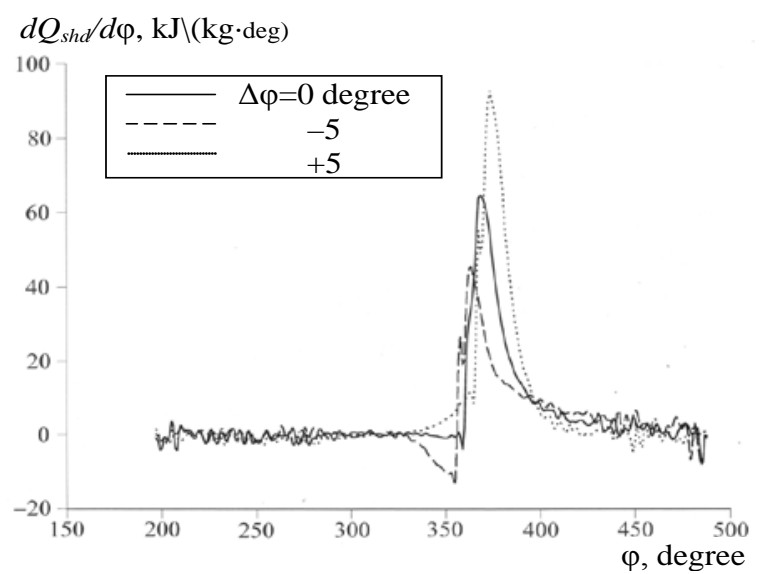

Fig. 7. Distortion of information on changes in the intensity of heat generation in the case of inaccurate definition of the upper dead point in the hard-soft environment

In general, it is recognized that the error of the experimental determination (marking) of the upper dead position of the engine piston by one degree of rotation of the crankshaft (which is less than $0.3 \%$ of its full revolution) generates the error of the determination of the average effective pressure by $p_{e} 6 \ldots .8 \%$, when it comes to a typical diesel engine, and $4 \ldots 6 \%$ in the case of a typical gasoline engine. Avoiding this error could be, by combining experimental means of research with analyticalgorithmic. Consequently, the success of any research - whether theoretical or experimental - is possible only if the system combines strength and analyticity. True, on the distorted indicator diagrams (see Fig. 5), the moment of effective ignition of the fuel mixture becomes more noticeable (it identifies the point, the area of the fracture of the graph of dependenc $p=p(S, \Delta \varphi \neq 0)$ ). 
It would be beneficial to distinguish turbulent and average. The material and thermal flows in the internal combustion engine are so nonstationary that the division of characteristics and quantities into medium and turbulent are always ambiguous. Often, the difference between a certain value measured in a certain one cycle, and its average value on ensemble (plural) of fixed cycles is taken for the turbulent pulsation of this value in this cycle. But in [12], for example, it is proved that the definition of turbulence based on simple averaging on the ensemble of work cycles is not suitable for flows in the internal combustion engine.

Of course, to determine the state of a working charge in the initial moment and its evolution in the process of compression and combustion, it is necessary to measure in time at the several points of three spatial components of velocity, pressure, density and concentrations in the process of compression and combustion. But this level is unlikely to be attainable in practice.

In fact, deviations from the very attractive "logarithmic linearity" (see Figure 4) can be significant, Fig. 8:

$c, b, r$-points corresponding to the momtnts of the forced inflammation of the mixture, the opening of the exhaust valve, the closure of the intake valve;

$p_{i}=0.318 \mathrm{MPa}$ - average display pressure;

$\Delta p_{i}=-3.5 \mathrm{\kappa Pa}-$ possible error $p_{i}$ of determination for errors in one degree of rotation in estimating the upper dead position of the piston;

$\theta=21$ deg - advance of inflammation at the angle of rotation of the crankshaft;

$\lambda=1.3$ - coefficient of excess air;

$n_{\mathrm{e}}=1400 \mathrm{~min}^{-1}$ - engine shaft speed.

Particularly noticeable, this deviation is usually in the area of developed combustion of fuel - after the upper dead point, not reaching the moment of opening the exhaust valve. Thus, the process of combustion of fuel, the process of heat generation must, of course, be described as something in a special way. The process of combustion noticeably affects, for example, the heat transfer in the walls of the cylinder, which will be emphasized later on.

One of the main problems of the development of an internal combustion engine with forced inflammation, intended for work on poor blends, is the development of ignition systems that would ensure reliable uninterrupted ignition of poor mixes in all possible modes of operation of the engine. In this direction, extensive research was carried out on the plasma-infrared ignition system in order to evaluate its suitability as a system of ignition for engines with a working volume of $1.4 \ldots 2.0 \mathrm{dm}^{3}$ working on poor blends [13].

The results of the studies at the initial stage of work have shown that in the case of low voltage inflammation system due to the high discharge current and its significant duration (approximately $50 \mathrm{~ms}$ ), the electrodes of the plasma inflammatory candle quickly wear out of erosion. Therefore, all further research was carried out with systems of high voltage inflammation.

The purpose of the research [13] is to identify the peculiarities of the influence of the plasma-jet ignition system on ignition and combustion of a homogeneous methane-air mixture in comparison with the usual inflammation system. Initial pressure in the combustion chamber was 0.5 MPa, initial temperature was $150{ }^{\circ} \mathrm{C}$. The combustion chamber had a diameter of $80 \mathrm{~mm}$ and a height of $80 \mathrm{~mm}$. In order to photograph the combustion process, a quartz window was provided. In Fig. 9 shows the dependence $z$ of the heat meter (continuous lines $P$ are related to plasma inflammation, dashes $S$ - ordinary, standard; $\lambda$ - excess air ratio). 


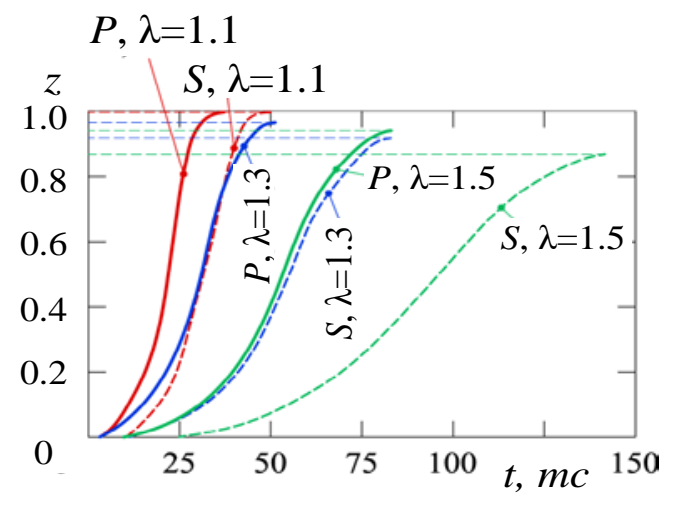

Fig. 9. Characteristics of heat generation
With $\lambda$ increasing, the ignition delay is less, and the combustion process runs faster and with greater integrity in the event of ignition of a plasma candle compared to a conventional candle. In the case of plasma inflammation, for $\lambda=1.5$ about $80 \mathrm{~ms}$, the heat transformation is about $94 \%$ of the initial mass of the mixture, and in the case of normal inflammation - $87 \%$ for $140 \mathrm{~ms}$.

The filming of the combustion process by the shirin-method showed that the methane-air mixture $\lambda=1.1$ in the case of plasma inflammation for $1 \mathrm{~ms}$ after the discharge ignited in a relatively large volume, whereas in the case of ordinary inflammation, only spot inflammation is observed.

An analytical description of heat generation, for example, depending on one or another factor, is an extremely difficult task. Although many of these factors are well known, consideration of their effects on the combustion process in formal terms is problematic, and an exhaustive mathematical description of the work process is practically impossible. Therefore, it has long been used by calculation empirical methods, in particular, within the framework of the Woschni and Anisitz approach, in which the influence of factors is determined experimentally.

So the heat generation process is identified by calculations on the basis of the taken off indicator diagram, the geometric parameters of the engine and the thermodynamic characteristics of the working body ... In summary, a characteristic of heat generation, which in itself is not suitable for meaningful interpretation of the combustion process, is obtained. Therefore, the analytical formulas are used to evaluate and compare the different characteristics of the heat emission between them.

One of the most successful and often used for describing the heat production process is the semiempirical function of I. Vibe, which was put forward in view of the kinetics of chemical reactions [14]. In the engines of fast combustion (gasoline, for example), the process of heat generation can be considered single-phase, that is described by one function of I. Vibe.

Instead, the combustion process in diesels (for example, in high-speed, unburnable combustion chambers) is rather two-phase, and therefore with the same precision in each phase, it can be described by the two functions of I. Vibe [15], the first of which is to reflect the analytical phase of the fast explosive combustion, and the second is the phase of slower diffusion combustion.

Yet hard-soft technology for simulating the workflow in the internal combustion engine allows you to identify the heating process, relying heavily on directly measured information. In this case, the approximation means (including the description of I. Vibe) would be more appropriate to add to this information already for the following theoretical generalizations.

The process of heat conversion into work is simplified in Fig. 10 rolled out by the angle of rotation of the crankshaft of the engine diagram (LDP and UDP- lower and upper dead points;

$B$ and $E$ - the beginning and the end of the high pressure region; $B_{c}$ and $E_{c}$ are the beginning and end of the combustion process). The heat $m_{\text {shd }} H_{u}$

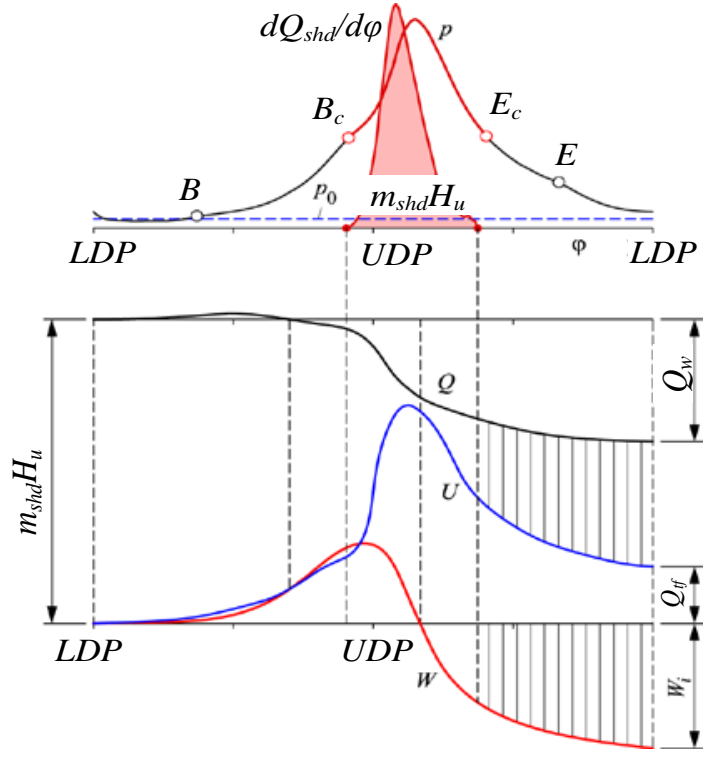

Fig. 10. Schematic diagram of the working cycle of a four-stroke internal combustion engine 
released in the process of combustion of fuel by mass $m_{\text {shd }}$ with the calorific value $H_{u}$, greatly enhances, first of all, the internal energy $U$ of the working body - the combustion mainly occurs in the vicinity of the upper dead point, $Q_{\text {shd }}$ - the current heat from combustion of fuel.

In the processes of compression, combustion and expansion into the walls of the working space, the heat $Q$ is diverted, only part of the heat is converted into mechanical work $W$. At the end of the working cycle, it is possible to recognize the indicator work $W_{i}$; heat $Q_{w}$ that was lost through the walls of the working space; output from exhaust gases outside the working space heat $Q_{t f}$ - payment for the possibility of obtaining mechanical work (the ordered mechanical energy from the disordered thermal).

It is not possible to radically change the distribution of heat for the mentioned components of the thermal balance, so the only way to improve the use of heat is to interfere with the process of heat generation: it is necessary to heat somehow so that the largest part of it becomes the work of expansion, that is, influenced the whole course of expansion.

The heat that has been allocated at the very beginning of the expansion process can be converted into work only in small quantities, instead it significantly increases the internal energy of the exhaust gases. On the other hand, since the rate of the reaction decreases with the decrease of the concentration of reagents, the combustion in the process of expansion slows down and stretches so that some of the fuel does not have time to react at all.

All studies are specifically aimed at accelerating and reducing the time of the final phase of the combustion process. A contributes to the reduction of the final phase of combustion, as is known, the turbulence of the charge movement in conjunction with the local increase in the concentration of fuel. It is on this problem that many researchers work by constructing special storage compartments.

Based on the general description of the heat transfer phenomenon and based on Newton's heat transfer equation and similarity theory

$$
Q_{w}=\alpha A\left(T_{g}-T_{w}\right), \quad \mathrm{Nu}=C \mathrm{Re}^{m},
$$

where $\mathrm{Nu}=\frac{\alpha d}{\lambda}$ and $\mathrm{Re}=\frac{w d \rho}{\mu}$, form the general equation for determining the heat transfer coefficient

$$
\alpha=C d^{m-1} \lambda\left(\frac{v \rho}{\mu}\right)^{m} .
$$

Here $\alpha$ is actual heat transfer coefficient; $Q_{w}$ is - the heat given to the wall of the cylinder; $A$ surface area of heat transfer; $T_{g}$ - temperature of gases in a cylinder; $T_{w}-$ wall temperature; $\mathrm{Nu}$ and $\mathrm{Re}$ are the criteria (numbers) of Nuselta and Reynolds; $C$ and $m$ - constants (take, for example $m=0.78$ ); $d$ and $w$ - characteristic dimensional and high-speed parameters; $\lambda$ - coefficient of thermal conductivity; $\rho$ - density; $\mu$ - coefficient of viscosity.

In addition, it is necessary to take into account the special influence on the heat transfer coefficient of the phenomenon of combustion of fuel. G. Woschni takes into account this influence with the help of an additional member, interpreting the speed accordingly. G. Hogenberg relies on the temperature of gases $T_{g}$, introducing corrections by means of a multiplier $\Delta$, the need of which can be verified only by means of measurements:

$$
\alpha=C d^{m-1} \lambda\left(\frac{w \rho}{\mu}\right)^{m} \Delta .
$$

The temperature of the gas $T_{g}$ appearing in (1) is most expedient to calculate the measured pressure using the thermal equation of the state of ideal gas

$$
T_{g}=\frac{p V}{m \mathrm{R}},
$$

where $m m$ and $V$ - mass and current volume of the gaseous working body;

$\mathrm{R}$ - gas constant. 


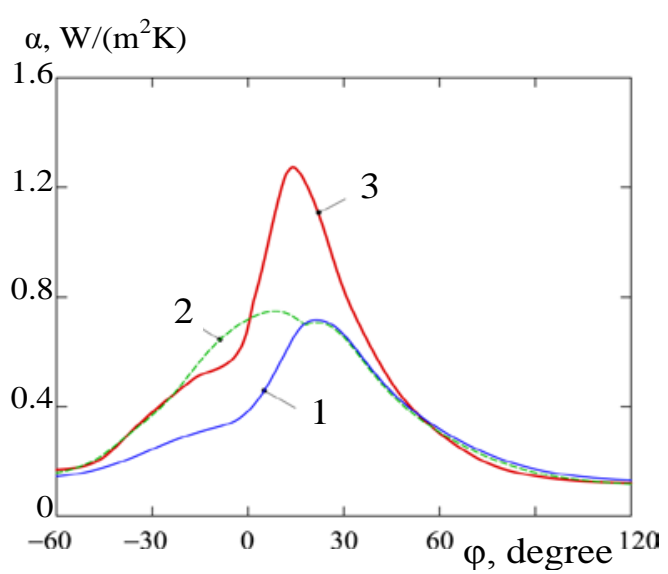

Fig. 11. Graphs of the change in the coefficient of heat output at the angle of rotation of the crankshaft
But the temperature of the walls $T_{w}$ the storeroom of combustion is estimated using a finite number of points of measured values. In the case of a diesel engine, the error provoked by the inaccurate determination of wall temperature can be traced mainly in the area of small loads. Instead, in the gasoline engine, the maximum temperature is approximately the same and much higher, which results in a greater temperature difference, and hence the error is always much lower. Since in brake modes, the temperature difference is always much smaller than in traction modes, in this case it is necessary to determine the temperature of the walls especially carefully.

The described technology allows you to determine at any time a number of those parameters that are absolutely necessary in the case of simulation of intra-system processes in the framework of generally accepted theoretical representations. At the same time, the level of information adequacy is much higher than what can be expected in the case of the classical approach to modeling. For example, we can draw a diagram (Fig. 11) which clearly shows the differences in determining the change in the coefficient $\alpha$ of heat transfer in the gasoline engine at the angle $\varphi$ of rotation of the crankshaft in the case of modeling by Voshny (curve 1 - the usual model, curve 2 - an improved model) and for analytical-full-scale model (curve 3).

Here already mentioned the problem of matching the turbulent and the average on the ensemble of work cycles. However, one should still pay attention to the notion of natural (physical) representativeness of the average.

It is clear that the average working cycle (whether arithmetic, geometrically or harmoniously) is an artificial formation, the accompanying processes in which physically are not interconnected.

For example, the "average” indicator diagram, which is intended to reflect the change in pressure in a cylinder with a change or its volume, or the piston stroke, or the angle of rotation of the crankshaft in a particular mode of the engine is physically not related to the corresponding "middle" diagram of the intensity change Heat generation, as with any other "average" chart. And it does not matter how many successive work cycles must reliably represent one or another mode of operation of the engine 100, 200 or 1000, given that each subsequent work cycle is generally not similar to the previous one, that the energy of ignition from cycle to cycle can There is a change in the drift of the moment of ignition, the amount of fuel that comes in the cylinder will differ, or else.

But by such parameters as the average, on the ensemble of working cycles the value $p_{i \text { sr }}$ of the so-alled average indicator pressure $p_{i}$ or $p_{e s r}$ the so-called average effective pressure $p_{e}$ (sometimes fuel supply, the maximum value of pressure ...), can be fixed the status of the objective value.

In this case, in a given ensemble of work cycles, there is one such value $p_{i}$ (or $p_{e}, \ldots$ ) in which the least differ from the fixed mean in the ensemble $p_{i s r}$ (or $p_{e s r}, \ldots$ ). In this case, this particular cycle and all information corresponding to it are in the sense of the average natural (physically) representative. In order not to provoke "fatigue" of the sensors, the number of successive working cycles in the ensemble should not exceed 100.

Quartz pressure sensors are capable of reacting only to change in pressure. Absolute value of pressure has to be determined from thermodynamic considerations. Several methods have been invented to find the zero line of the indicator diagram. The most stable and most accurate way is considered by $\mathrm{G}$. Gogenberg, the essence of which is the following.

The process $\left[A_{1}, A_{2}\right]$ of compression of a mixture of fuel at a certain interval $\left[V_{1}, V_{2}\right]$ of change of working volume (often from 10 deg after the closure of inlet valves up to a moment of inflammation of the working mixture) is difficult to distinguish from polytropic, see. Fig. 4 (as well as Figure 8). There- 
fore, guided by the assumption that the compression polytope is somewhere in the region between 100 and 65 degrees of the angle of rotation bending to a higher dead point, one can determine the displacement of the zero line $\Delta p_{n}$ by means of such an equation:

$$
\Delta p_{n}=\frac{\Delta p}{\left(V_{1} / V_{2}\right)^{n}-1}-p_{2}, \quad \Delta p=p_{1}-p_{2},
$$

where $n=\frac{\ln p_{1} / p_{2}}{\ln V_{2} / V_{1}}-$ polytropic index. In order to minimize the effect of the local pressure variation instead of the pressure values $p_{1}$ and $p_{2}$ corresponding to Fig. 4 exactly points $A_{1}$ and $A_{2}$, it makes sense to take the average arithmetic values at the boundaries of the nodes of these points, bounded by \pm 2 degrees of turning bending.

It is known that the accuracy of \pm 50 mbar can be achieved by G. Hohenberg's method. It is quite enough for the general application of the algorithm. But from a separate (on the basis of the analysis of the flow of pressure), the study of heat transfer in the brake operating modes of the engine requires accuracy of \pm 10 mbar. In order to achieve it, an improved but costlier method of finding a zero line was developed.

In some studies, it was proposed to move the zero line iteratively until the total calculated heat generation at the beginning of the combustion would become zero (in braking conditions, it is necessary to find an acceptable position of the angle of rotation of the kneeling when compressing the mixture). The disadvantage of this method is the poor convergence (convergence) of the iterative process.

In the end, for a particular high precision requirement, it is suggested to rely on the equation of the first law of thermodynamics with zero line displacement

whence

$$
\frac{d U}{d \varphi}=\frac{d Q_{w}}{d \varphi}-\left(p+\Delta p_{n}\right) \frac{d V}{d \varphi}+\frac{d m_{\mathrm{air}}}{d \varphi} h
$$

$$
\Delta p_{n}=\frac{\frac{d Q_{w}}{d \varphi}-\frac{d U}{d \varphi}+\frac{d m_{\mathrm{air}}}{d \varphi} h}{d V / d \varphi}-p
$$

where $U$ - internal energy;

$m_{\text {air }}$ - mass of air;

$h$ - specific enthalpy;

$Q_{w}$ - heat that penetrates through the walls of the working space;

$\varphi$ - angle of rotation of the shaft of the engine.

But $\Delta p_{n}$ can be determined only iteratively, since the calculation of temperatures with the help of the general equation already requires corrected pressure. It is necessary to linger until it is believed until a sufficiently small pressure shift is achieved

$$
\frac{1}{N} \sum_{\mathrm{i}=1}^{N} \Delta p_{i}<1 \text { mbar, }
$$

where $N$ - number of iterations.

The displacement of the zero pressure line in the process of combustion is chosen in the range of bending angles of the knee from 10 deg after the closing of the inlet valve to 5 deg before the moment of beginning of ignition (in braking modes - to the highest dead point in the compression process). Convergence is good - the desired result is achieved in four steps.

\section{Conclusions}

1. In a fixed software environment (such as CFD Code AVL FIRE, for example), there are preestablished rigid frameworks for cognitive abilities, which can be expanded only by adding the natural working space of the internal combustion engine to the usual software and algorithmic environment. That is, naturally, the idea of engaging in the model is quite real work engine space, systematically combining it with the virtual engine embodied in the computer program, thus introducing part of reali- 
ty into the model of this reality. Consequently, in different forms and in different proportions, one must observe each other's analyticity and empiricity, formality and physicality (materiality), virtuality and reality...

2. For the simulation of thermal phenomena in engine cylinders, a system of three descriptions is used in various forms: the equation of the energy conservation law, the equation of the law of conservation of matter (matter), and the equation of the thermodynamic state of the working body. But in general, to "integrate", if you can say so, this system of equations, in any form, can only be a reality without fail. Indeed, "inviting" the particle of reality into a model, under any conditions, in the framework of any theory (formal paradigm), we will necessarily receive the best result of knowing the properties of the engine.

However, there is no means for perfect measurement of pressures, temperatures, and more. And therefore, virtual virtual means of disclosing the contents of information obtained with the help of experimental tools come to the aid.

Thus, the harmonious combination of a model model and a virtual model within any paradigm allows us to deepen the knowledge of the laws of producing mechanical energy in a thermal engine.

3. Based on the general description of the heat transfer, and based on the Newton's heat transfer equation and the theory of similarity, nevertheless, when it comes to the question of an adequate estimation of heat transfer through the walls of the working space of the engine, it is necessary to resort to corrective actions that can be carried out only with the help of direct measurements. It is the direct measurements in the physical environment of the temperature parameters of the working space of the engine to create an information basis for theoretical generalizations in the virtual environment. For example, the coefficient of convective heat transfer in the natural environment is only abstraction, without which, however, can not do in the virtual environment. But to estimate such theoretically significant value has to be indirect by "real" measurements.

4. In each ensemble, in the sequence of identified work cycles, there is one such value of the average indicator pressure $p_{i}$ (or average effective pressure $p_{e}, \ldots$ ) in which the least differ from the fixed mean of $p_{\text {isr }}\left(\right.$ or $\left.p_{\text {esr }}, \ldots\right)$ of this value in the ensemble. In this case, this particular cycle and all information corresponding to it are in the sense of the average natural (physically) representative. In order not to provoke the "fatigue" of the sensors, the number of successive working cycles in the ensemble should not exceed 150. The formal averaging of all controlled / measured values leads to the synthesis of a certain fictitious working cycle in which the physically determined connections between these quantities and influential factors.

\section{Література}

1. Гащук П., Богачик Ю. Аналітичні засоби моделювання процесів теплотвореннятеплоспоживання в двигуні 3 яскровим запалюванням на ялових режимах його роботи. Проектування, виробництво та експлуатація автотранспортних засобів та автопоїдів : Праці Західного наукового центру Транспортної академії України. Львів. 1995. Т. 1. С. 34-51.

2. Гащук П. М., Нікіпчук С. В., Богачик Ю. О. Натурно-машинні засоби в моделюванні термодинамічних процесів, що перебігають у двигунах внутрішнього згоряння. Вісник Державного університету “Львівська політехніка”: Динаміка, міцність та проектування машин і приладів. Львів. 1998. № 354. С. 3-9.

3. Clausius R. Die mechanische Wärmetheorie. Band 1.- 3 Auflage. Braunschweig: Druck und Verlag von Friedrich Vieweg und Sohn. 1887. XVI. 403 p.

4. Rankine W. J. M. A manual applied mechanics : 6 ed. London : Charles Griffin and company, 1872. XVI. 648 p.

5. Tisza Laszlo. Generalized Thermodynamics. Cambridge (Massachusetts). London : The M.I.T. Press, 1966. 384 p.

6. Möhlenkamp Heinrich. Zur Genauigkeit der Brenngesetzrechnung eines Dieselmotors mit nichtunterteiltem Brennraum. MTZ. 1976. 37, № 7-8. P. 285-291.

7. Гащук П., Богачик Ю. Особливості внутрішнього теплопереносу в двигуні з яскровим запаленням за різних навантажень. Проектування, виробництво та експлуатація автотранспортних засобів $i$ поїздів: Праці західного наукового центру Транспортної академії наук. Львів. 1995. Т. 2. С. 12-15.

8. Oppenheim A. K. Quest for controlled combustion engines. SAE Techn. Pap. Ser. 99, 1988. № 880572. P. 1-8.

9. Remboski D. I., Rhee S. L., Martin J. K. An optical sensor for spark-ignition engine combustion analysis and control. SAE Techn. Pap. Ser. 1989. № 890159. P. 1-14. 
10. Thiemann Wolfgang. Verfahren zur genauen Zylinderdruckmessung an Verbrennungsmotoren - Teil 1. MTZ: Motortechn. Z. 1989. 50, № 2. P. 81-84, 87-88.

11. Thiemann Wolfgang. Verfahren zur genauen Zylinderdruckmessung an Verbrennungsmotoren - Teil 2. MTZ: Motortechn. Z. 1989. 50, № 3. P. 129-134.

12. Bracco F.V. Modeling and diagnostics of combustion in spark-ignition engines. ATA -Ingegneria automotoristica. 1988. 41, № 5. P. 373-385.

13. Adams Willi, Birsztejn Thomas, Kupe Joachim, Wilhelmi Herbert. Ein neu entwickeltes plasmastrahlzündsystem zur Verbrennung von magergemischen. MTZ: Motortechn. Z. 1988. 49, № 12. P. 515-519.

14. Гащук П. М., Нікіпчук С. В. Теплотворення в двигуні швидкого внутрішнього згоряння. Mechanics and Advanced Technologies. 2018. \#1 (82). C. 92-99. DOI: http://dx.doi.org/10.20535/25211943.2018.82.125201.

15. Stas Marek, Wajand Jan. Bestimmung der Vibe-Parameter für den Zweiphasigen Brennverlauf in Direkteinspritz-Dieselmotoren. MTZ: Motor-techn. Z. 1988. 49, №. 7-8. P. 289-293.

\section{References}

1. Hashchuk, P., \& Bogachik, Y. (1995). Analytical means for simulation of heat production-heat consumption in an engine with a spark plug in firing modes of its operation. Design, manufacture and operation of motor vehicles and trains: Proceedings of the Western Scientific Center of the Transport Academy of Ukraine, 1, 34-51.

2. Gashchuk, P. M., Nikipchuk, S. V. \& Bogachik, Y. O., (1998). Natural-mechanical means in simulation of thermodynamic processes that run in internal combustion engines. Bulletin of the State University "Lviv Polytechnic": Dynamics, strength and design of machines and instruments, 354, 3-9.

3. Clausius, R. (1887). Die mechanische Wärmetheorie. Braunschweig: Druck und Verlag von Friedrich Vieweg und Sohn.

4. Rankine, W. J. M. (1872). A manual applied mechanics. London: Charles Griffin and company, 6 ed.

5. Tisza Laszlo. (1966). Generalized Thermodynamics. Cambridge (Massachusetts). London: The M.I.T. Press.

6. Möhlenkamp Heinrich. (1976). Zur Genauigkeit der Brenngesetzrechnung eines Dieselmotors mit nichtunterteiltem Brennraum. MTZ, 37(7-8), 285-291.

7. Gashchuk, P., \& Bogachik, Y. (1995). Peculiarities of internal heat transfer in the engine with ascorbic inflammation at different loads. Design, manufacture and operation of motor vehicles and trains: Proceedings of the Western Scientific Center of the Transport Academy of Sciences, 2, 12-15.

8. Oppenheim, A. K. (1988). Quest for controlled combustion engines. SAE Techn. Pap. Ser., 99(880572), 1-8.

9. Remboski, D. I., Rhee, S. L., \& Martin, J. K. (1989). An optical sensor for spark-ignition engine combustion analysis and control. SAE Techn. Pap. Ser., 890159, 1-14.

10. Thiemann Wolfgang. (1989). Verfahren zur genauen Zylinderdruckmessung an Verbrennungsmotoren Teil 1. MTZ: Motortechn. Z., 50 (2), 81-84, 87-88.

11. Thiemann Wolfgang. (1989). Verfahren zur genauen Zylinderdruckmessung an Verbrennungsmotoren Teil 2. MTZ: Motortechn. Z., 50 (3), 129-134.

12. Bracco, F.V. (1988). Modeling and diagnostics of combustion in spark-ignition engines. ATA Ingegneria automotoristica, 41 (5), 373-385.

13. Adams Willi, Birsztejn Thomas, Kupe Joachim, \& Wilhelmi Herbert. (1988). Ein neu entwickeltes plasmastrahlzündsystem zur Verbrennung von magergemischen. MTZ: Motortechn. Z., 49 (12), 515-519.

14. Hashchuk, P. M., \& Nikipchuk, S. V. (2018). Heating (thermogenesis) in rapid internal combustion engine. Mechanics and Advanced Technologies. 1 (82). 92-99. DOI: http://dx.doi.org/10.20535/25211943.2018.82.125201.

15. Stas Marek, \& Wajand Jan. (1988). Bestimmung der Vibe-Parameter für den Zweiphasigen Brennverlauf in Direkteinspritz-Dieselmotoren. MTZ: Motor-techn. Z., 49 (7-8), 289-293.

Гащук Петро Миколайович; Hashchuk Petro, ORCID: https://orcid.org/0000-0002-2345-4879

Нікіпчук Сергій Вячеславович; Nikipchuk Serhij, ORCID: https://orcid.org/0000-0003-2499-9990 